\title{
Background Paper: Incorporating the Defence Sector into Public Expenditure Work
}

This article is an extract from a paper prepared for the international workshop »Incorporating the Defence Sector into Public Expenditure Work«, February 9-10, 2004, Bonn, Germany. The Peacebuilding and Good Governance Division of the Netherlands Ministry of Foreign Affairs took the lead in drafting this paper.

\section{Background}

The »Utstein Group Seminar on Security Sector Reform in Africa « held on December 13, 2002 sought to identify concrete opportunities for cooperation between the Utstein partners on »Security Sector Reform (SSR) in specific regions/countries in Africa. ${ }^{1}$ One opportunity for cooperation identified at this meeting was »Public Expenditure Management (PEM) in the defence sector «. The Utstein members recognised that the World Bank, with its experience in public expenditure work, would be a crucial partner in moving forward in this area. Thus, the Utstein Group supported the initiative taken in 2003 by Minister for Development Co-operation of the Federal Republic of Germany Heidemarie Wieczorek-Zeul in proposing to World Bank President James Wolfensohn a joint exploration of the ways in which the World Bank, other international actors, and bilateral donor governments could assist their development partners to strengthen the quality of financial management in the defence sector.

Section 1 of this paper addresses the linkages between human security, poverty alleviation, and sustainable development. Section 2 considers the linkages between human security and governance. Section 3 discusses one of the key pillars of democratic governance of the defence sector, »sound financial governance«. The instruments available to donors to promote sound financial governance in the defence sector and potential areas for donor co-operation in the area of public expenditure work are identified in section 4. Finally, section 5 proposes the practical application of the issues discussed in sections 3 and 4.

\section{The Poverty-Insecurity Trap: Why Security is a Sustainable Development Issue}

The World Bank report Voices of the Poor recognises insecurity as one of the main perils for the poor. ${ }^{2}$ The poor are disproportionately

1 The Utstein members participating in this seminar were Germany, the Netherlands, Norway, Sweden and the United Kingdom. Later in the process, they were joined by Canada as a new member of the Utstein Group.

2 The reports in this series can be found at http://www.worldbank.org/poverty/voices/reports.htm. They reflect the shift from defining security narrowly in military terms as "protection from territorial and sovereignty threats to a broader definition that includes the security of individuals and communities, or »human security«. »Human security« was first defined in the 1994 UNDP Human Development Report. According to UNDP, human security implies protection from systemic human rights abuses, physica threats, violence and extreme economic, social and environmental risks. The Human Security Network was established in 1999, and defines human security as »freedom from pervasive threats to people's rights, their safety or even their lives. "The Human Security Commission, chaired by Dr. Amartya Sen and Mme. Sadako Ogata, take a broader view. According to the Commission, human security integrates the main agenda items of peace, security and with those aspects of development that related to threats to life and health. Irrespective of which definition one adopts, the concept of human security seeks to put the individual, rather than the state or the government of the day, at the centre of security policy. affected by insecurity - both poor people and poor countries. Insecurity for people can result both from an absence of security institutions and from the arbitrary actions of security institutions. The debilitating impact of insecurity on poverty-alleviation and sustainable development objectives works through the following mechanisms:

- Poor governance of the security sector leads to unaccountable security forces, which themselves can be a major source of insecurity.

- High and inefficient defence expenditure can crowd out developmental spending. Together with insecurity, this can have a knockon effect by eroding both human capital (through reduced psychological and physical health) and social capital (through lack of trust and collaboration) as well as by retarding necessary improvements in physical infrastructure.

- Significant insecurity and low levels of human and social capital and public infrastructure render a country unattractive for investment, as investors rate insecurity as their number one risk.

- The cumulative effects of insecurity and poverty impair prospects for the future by reducing incentives to invest in productive assets and to expand employment.

- The lack of coordination of security sector management and security sector architecture design leads to a lack of cooperation, rivalry and thus inefficiency across the sector.

In sum, the rationale for including security in the sustainable development agenda is threefold: (1) while whole societies are impacted, the people most affected by insecurity are the poor; (2) the poor see insecurity as a central source of ill-being; and (3) poor countries often lack the capacity to address security issues, thereby creating a poverty-insecurity trap. SSR should therefore be an integral part of development assistance, especially in post-conflict countries, which are particularly prone to revert into violent conflict. ${ }^{3}$

\section{Why Donors Should Promote Democratic Governance in the Security Sector}

Just as there is increasing agreement that state and human security is critically important for sustainable, poverty-reducing development, a consensus is building that in order to achieve a secure environment a country's security bodies must be subject to the rules of civil democratic governance. Security bodies that are poorly managed and that engage in political and economic impunity tend to be professionally weak and therefore are unable to adequately protect the state and individuals against aggression, internal subversion, criminality and other security problems. In many cases, these weaknesses are tied to the quality of democratic governance in the security sector. By the same token, politicised or ineffective security bodies and jus-

3 To ease the post-conflict insecurity that tends to result from hostilities, it is also necessary to focus on reconciliation opportunities, enhance the legitimacy of state institutions, and increase possibilities for recovery and economic development. 
tice systems are themselves a source of the instability and insecurity that can undermine the capacity for development and democratic consolidation.

One of the central tenets of democratic governance of the security sector is that, from a public policy and process perspective, security shares many of the characteristics of other sectors and that the population of any country will benefit from a security sector that is subject to the same broad set of rules and procedures applied in other sectors. This requires civil democratic control and oversight of the security sector, professionalism of the security bodies, adherence of the security sector to the rule of law, demilitarisation of society, and strengthening regional capacity in peacebuilding, and security sector expenditure management. ${ }^{4}$

Undemocratic processes can lead to allocations that do not represent people's needs and wishes. Such decisions are likely, rather, to reflect the interests of those in power, and may privilege those institutions that keep them in power, including the military. Even where those in power are not greatly reliant on security bodies, the defence sector generally receives a sufficiently large allocation to make it imperative that defence competes fairly with other government priorities and that processes are transparent and accountable.

In the context of providing development assistance, many donors are dissatisfied with the large share of developing and transition countries' central budgets allocated to defence spending. Consequently, the level of defence expenditure is raised as a matter of political dialogue or of conditionality. These efforts can be challenged on several points: (1) they underestimate real security threats that countries might face, and undervalue non-military forms of security, (2) they stimulate »creative accounting « and the search for other (off-budget) sources of income (see Box 1), and (3) they focus too much on the level of expenditure and underestimate the serious human and institutional capacity gaps faced by developing and transition governments in managing the process of defence spending.

A more comprehensive and effective approach would be to combine political dialogue with assistance to partner countries in order to develop affordable security services and to place a high priority on transparency and accountability of the security sector.

It is appropriate and necessary for international assistance to promote a transparent and accountable defence sector in developing and transition countries as part of development assistance for the following reasons:

- Sound budgeting and financial management in the defence sector is crucial for sustainable, poverty-reducing economic development.

- The inadequate transparency and accountability of the defence budget, contributes to the so-called »poverty-insecurity trap «.

- A non-transparent and unaccountable defence budget undermines democratic governance of the defence sector and democratic forms of government in general.

- The shift in donor support from project funding to budgetary support and sector-wide reforms requires greater transparency in the management of all public finances, including those in the defence sector.

One important means of promoting civil democratic control, transparency and accountability of the defence sector is to ensure that it is fully integrated into public expenditure work and in the dialogue on PEM. Efforts to achieve an affordable level of defence spending will not succeed absent the political will to apply PEM principles and practices to the defence sector and the capacity to manage and oversee the defence budgeting process. A major objective of incorporating the defence sector into public expenditure work is precisely to generate the necessary political will and strengthen existing human and institutional capacity. (Box 2 provides brief examples of how these principles are applied in OECD countries.)

4 Security bodies include all bodies legally mandated to protect the state and its population, including armed forces, police and paramilitary forces, and intelligence services.
In view of the attention that development donors have given to defence spending in the past and the large proportion of the resources allocated to security in most partner countries that is absorbed by the defence forces, this paper focuses on the defence sector. Nevertheless, most of the problems and recommendations that are discussed hereafter apply to all security bodies.

\section{Box 1}

\section{Reliability of Data on Defence Spending}

Data on defence expenditure are notoriously unreliable. While the data for OECD countries tend to be more accurate than those in developing and transition countries, figures for these countries also should be interrogated closely to determine the true level of expenditure. For example, national definitions of military expenditure vary substantially among OECD member countries, while significant portions of some country's defence budgets may be funded outside the defence budget.

Additionally, the definitions of military spending by international organisations such as NATO and the OSCE can produce substantially different numbers than national definitions, but OSCE numbers are not published and NATO data are only published in highly aggregated formats.

The main reasons why figures for »defence« in national accounts may be inaccurate are:

- Defence-related expenditures/revenues are kept off-budget.

- Budget categories are highly aggregated, making it impossible to determine what is included and what may be missing.

- Items of expenditure included in the defence budget may be diverted to other uses, including personal use by senior military officers and/or senior political officials.

- Defence-related expenditures appear in non-defence budget categories, such as debt repayment, office of the president, atomic energy commission and so on.

- Disagreement over whether an item is defence-related or not, such as pensions for military personnel.

- Military assistance is not included in budget estimates.

- Decentralized military units operate their own budgets, with little central control.

- Civil management and oversight bodies are weak vis-à-vis the defence sector.

- Actual spending is not, or only very belatedly, reported; national accounts are largely based on plan data.

\section{Sound Financial Governance in the Defence Sector}

Security, like health care and education, is a public good and a prerequisite for creating an environment in which sustainable povertyreduction and economic and social development can be fostered. This means that it is both appropriate and necessary for the state to allocate resources to that sector. However, to maximise the effectiveness and efficiency of the use of these resources, they must be managed in a transparent and accountable manner.

Civil management and oversight bodies are weak vis-à-vis the defence sector. As far as the defence sector is concerned, there are good reasons for giving expenditure management high priority. The common practices in the defence sector tend to deviate, often significantly, from PEM principles of sound budgeting and financial management. Some of the most significant deviations derive from inadequate civil democratic control: the privileged position of defence in the competition for public funding; the lack of information about expenditure hidden under the cloak of secrecy; weak monitoring and oversight of defence expenditure; the high value of defence contracts and the scope for corruption and mis-procurement; and large amounts of off-budget revenue/expenditure. ${ }^{5}$ 


\section{Box 2}

\section{Application of PEM to Defence in OECD Countries}

The preferred defence budgeting process in many OECD countries is PPBS (Planning, Programming, Budgeting Systems), first applied in the United States in the early 1960s.

- Planning involves identifying priorities for the military. It often involves the development of future threat scenarios, from which priorities for preparedness are derived. The US, for instance, currently wants its military to be prepared to fight in two major wars simultaneously, in addition to fulfilling routine functions. Planning is undertaken by military and civilian specialists on strategy, but decisions are taken by the political leadership. Financial considerations limit the number of options even at this stage.

- Programming involves the military units and equipment needed for the tasks set in the planning stage. Programming can be done for particular missions or functions, or for predetermined force elements. Programming generally is the prerogative of military specialists.

- Budgeting at this stage involves costing the military units, their equipment and operational expenditures. This is generally done by specialists, uniformed and civilian, within defence ministries, but also involves input from many sources within the organisation. If the proposed spending is not affordable, planning and programming have to be redone.

An alternative system, which is sometimes used to complement PPBS, is zero-based budgeting, where the effects of reductions of budget categories to zero are compared in order to arrive at priorities for spending.

OECD countries generally do not run the full planning phase every year, only at specific time periods (every four years in the US, the so-called quadrennial review), or when significant changes in the security environment create a need for review, for instance in a Defence White Paper (as the UK did in 2003 following NATO enlargement, September 11, and expanded requirements for peace support operations). Annual PPBS applications generally rely on small adjustments of planning to changes in circumstances. Financial constraints also often prevent the full application of PPBS, with spending limitations set and budgets developed

Off-budget defence expenditure/revenue is particularly pernicious as it undermines economic development through its impact on the overall budget planning and execution process, macro-economic stability, and defence cost-effectiveness. ${ }^{6}$ The high level of off-budget defence expenditure/revenue in many partner countries is a manifestation of their weak capacity to improve democratic control, transparency and accountability in the defence sector. Off-budget expenditures and revenue are especially likely to occur in countries characterised by:

- A large and autonomous defence sector.

- Direct military representation in the political institutions.

5 D. Hendrickson, and N. Ball, Off-budget Military Expenditure and Revenue: Issues and Policy Perspectives for Donors. CSDG Occasional Papers \# 1. London: Department for International Development (DFID) \& King's College, 2002, p. 6. Off-budget military expenditure and revenue have a budgetary and extra-budgetary dimension. Some of the more common budgetary mechanisms for disguising military spending include: (1) contingency funds; (2) supplementary budgets; (3) spending under nondefence budget lines; (4) non-transparent or highly aggregated budget categories; and (5) diversion of resources from non-defence budget lines. Extra-budgetary sources of military revenue include: (1) parastatals; (2) military-owned businesses/involvement in non-military activity; (3) creation of funds; (4) barter trade; (5) direct financing of military in field through extraction of natural resources; (6) war levies; (7) foreign military assistance; (8) donor support for military demobilisation and reintegration programmes; (9) informal/criminal activities; and (10) under-valuation of economic resources.

6 Hendrickson and Ball, (2002).
- A strong executive decision-making culture.

- Significant security problems, including armed conflict.

- A post-conflict situation. and

- Military involvement in the commercial exploitation of natural resources.

To address these expenditure/revenue problems, the integration of defence into the planning, policy-making and budgeting systems and processes of a country in a manner consistent with sound budgeting and financial management principles and practices should be prioritised. In practical terms, this means that:

- Civil authorities should signal clearly that they intend for the defence sector to compete for state resources on an equal footing with other parts of the public sector.

- Defence budgets should be prepared based on a sectoral policy and strategy.

- Defence policies must be affordable, and reconciled with competing claims on the overall public budget.

- Resource allocation within the defence budget should be according to agreed security priorities.

- Deviations between budgeted and actual expenditure should be avoided. ${ }^{7}$

- Large amounts of off-budget expenditure/revenue should be avoided.

- Resources allocated to the defence sector should be used effectively and efficiently.

- Resource use should be closely monitored by external oversight bodies with enforcement capacity.

Although small adjustments in budgeting practices may be required to address national security concerns, these should in no way compromise PEM principles. In particular, most defence budgeting specialists agree that while some degree of confidentiality may be warranted to protect national security interests, there should be a high degree of transparency in the defence budget and procedures should be developed to ensure that civil oversight is maintained. Spending should be subject to scrutiny by the legislature, while national security issues may require some forms of expenditure being handled in closed committee hearings.

As part of a decision to apply PEM principles to the security sector, a significant effort will in most cases have to be put into capacity building of involved actors. The lack of experience and confidence of staff within ministries of finance and auditor general offices when dealing with security and accountability issues is a significant problem that needs to be addressed on a priority basis. Training for relevant staff in security sector management issues and the language of the security organisations would be very beneficial in providing these management and oversight actors with the tools to undertake their roles effectively. The same is true for parliamentary oversight committees, e.g. the public accounts committee and security-related committees. ${ }^{8}$

\section{Incorporating Defence into Public Expenditure Work}

There are five inter-related components to managing public expenditure in any sector: 1 ) sectoral/strategic planning; 2) reviewing previous year's performance; 3 ) determining what is affordable for the entire public sector; 4) allocating resources by sector; and 5) using resources efficiently and effectively. For these processes to be effec-

7 N. Ball and M. Holmes, Integrating Defense into Public Expenditure Work Paper commissioned by UK Department for International Development, January 11, 2001, http://www.grc-exchange.org/docs/SS11.pdf.

8 Additional problems can occur where the head of state, doubling as minister of defence, provides the defence sector with favourable status and additional resources. Not only may this give the defence sector preferential access to public resources, it can also limit a crucial aspect of civil oversight which could be brought to bear by a dedicated minister of defence. At the same time, it should be recognised that simply replacing the head of state, or a serving military officer, with a civilian minister of defence will not, by itself, solve problems of accountability and transparency. The political will to place the defence sector and other parts of the security sector on an equal footing with the rest of the public sector must exist. 
tive, each sector needs to follow good practices internally and to link with the broader government-wide fiscal management and oversight process. All of this must occur within the framework of democratic governance and the principles of sound budgeting and financial management. ${ }^{9}$

With their extensive global experience in public expenditure work, the World Bank and the IMF are crucial partners in moving forward on the issue of incorporating the defence sector into the public expenditure domain. It will be important to identify the competencies and approaches of all donors and specialised agencies in this area to promote a workable division of labour among involved actors. This section discusses the World Bank and IMF approaches to public expenditure work, some of the PEM instruments available, and potential areas for donor co-operation in this area. It makes no pretensions to completeness. Further exploration of these possibilities is the next step in moving the »defence and PEM « agenda forward.

\subsection{The Scope for Integrating Defence in World Bank and IMF work on PEM}

World Bank work related to the defence sector is guided by two documents: "Note on Military Expenditure «10 and »The General Counsel's Statement on Whether Public Expenditure and Military Expenditure in Particular Fall Within the Bank's Mandate «11. Mr. Wolfensohn, in his response to Minister Wieczorek-Zeul's letter, stated that the World Bank was open for further dialogue on the subject, while noting the organisation's constraints on working in the defence sector as defined by its Articles of Agreement. In general, the Bank can only respond to specific requests from the government for assistance in integrating defence in its advice on public expenditure management.

The Bank has developed a range of diagnostic mechanisms that could, in principle, also be employed to help improve financial management in the defence sector, if so requested by a member country. Some important instruments employed by the World Bank and other donors are shown in Box 3.

The Fund's role in the area of military spending is in large part determined by its mandate. With regard to military spending, the Fund is engaged in three specific areas. The first involves improving the quality of expenditure data. (More detail is found in Box 4.) Second, the fund provides technical assistance on fiscal statistics and work on fiscal transparency to that has helped help improve the reporting of military spending. Specifically, Fund technical assistance has helped countries improve the reporting of data on a functional basis, including military outlays, and strengthen systems for reporting public expenditure more generally. The latter can improve the quality and timeliness of data on budget outturns, which can help improve reporting of data on military outlays. Third, the Fund often analyses the policy implications of military spending. In particular, Fund staff have conducted cross-section analyses of the impact of conflict, reduced levels of military spending, and inadequate fiscal transparency on economic growth and the composition of expenditure. Where the authorities are contemplating military demobilization, Fund missions are also expected help countries analyse the macroeconomic and fiscal effects of these measures, including the need for increased spending on social safety nets.

The Bank and Fund have recently proposed a new collaborative approach to public expenditure work, the key features of which are 1) responsiveness to a country-led strategy for public expenditure reform, 2) donor coordination in undertaking diagnostic work so that transactions costs to governments are reduced, 3) coordinated

9 A detailed description of how budgetary outcomes in the defence sector can be improved is found in Ball and Holmes (2001), section IV.

10 World Bank Operational Memorandum, SecM91-1563, December 9, 1991. This note references the role of the Fund in seeking aggregate data on fiscal expenditure including military expenditure.

11 December 13, 1991. technical and financial support to governments for reform implementation, and 4) periodic assessment of performance of the budget system. Consistent with the Monterrey consensus, this approach puts the main responsibility for improved governance on the aidreceiving countries while placing the responsibility of aid-givers to support reforms with coordinated technical and financial assistance.

\section{Box 3}

World Bank Analytical Instruments used in Public Expenditure Work

The World Bank currently employs three principal reviews to assess public expenditure policy and management in member countries. These are the Public Expenditure Review (PER), the Country Financial Accountability Assessment (CFAA) and the Country Procurement Assessment Review (CPAR).

- PERs assess both the policy aspects of public expenditure (such as its fiscal sustainability, efficiency and equity) as well as aspects of its management (including the processes governing budget formulation and execution).

- The World Bank's CFAA and CPAR are instruments that assess the effectiveness of accountability for financial management (including the quality of audit arrangements and accountability to the legislature) and the appropriateness of procurement rules and procedures.

The World Bank also selectively undertakes Public Expenditure Tracking Survey (PETS) to assess whether resources effectively flow to front line agencies.

The Institutional and Governance Review (IGR) is another instrument used selectively to assess broader issues of governance and related institutional matters.

\subsection{Areas of Potential Donor Collaboration}

The members of the development community bring different competencies to the table. The Bank is of course well suited to lead on the core public expenditure management areas, and World Bank PEM processes and instruments should be reviewed for their applicability to the defence sector, taking into account specific defence-sector concerns and considerations. At the same time, while the mechanisms discussed in section 4.1 are primarily World Bank mechanisms, other donors frequently play a role in their application. ${ }^{12}$ Some donors support public expenditure work directly, for example by providing staff or consultants to participate in PERs, by taking the lead on core activities such as expenditure classification projects, and by providing technical assistance to ministries of finance, offices of the auditor general and the like. (Box 5 describes the capacity of selected Utstein member governments to support public expenditure work in the defence sector.) Furthermore, the Bank is not particularly well suited to overseeing the development of sectoral policy and strategy in the security sector. The existence of policies and plans against which to budget are an essential element of sound public expenditure management practice, and this would be an area where the bilateral donors should consider taking the lead.

The 2000 Ethiopia PER offers a good example of a collaborative effort between the government of Ethiopia and a multi-donor team, including multilateral institutions and bilateral development partners, with a division of work on PER topics. ${ }^{13}$ This PER integrated the defence sector through an assessment of the fiscal impact of the bor-

12 More broadly, all of a country's donors participate in Consultative Group (CG) meetings, while CASs, TSSs and PRSPs are approved by the Bank's Board of Executive Directors, on which all bilateral donor governments are represented.

13 World Bank (2000). Ethiopia Public Expenditure Review, Volume I: Main Report. Report No. 20810-ET, World Bank Country office in Ethiopia, Country Department 6, Africa Region. 
Box 4

\section{The IMF and Military Spending}

The Fund's Executive Board has confirmed that in the context of Fund surveillance of a member's policies, Fund staff should request data required to assess the country's macroeconomic policies. At a minimum, this requires all member countries to provide the Fund with comprehensive data (of both the budget and balance of payments) capturing all expenditures, including off-budgetary spending. These data should encompass military transactions, even if not separately identified. Data deficiencies that impair the ability to assess a member's macroeconomic policies are brought to the attention of the Executive Board Military spending data do not serve as a basis, however, for established performance criteria or similar conditions in Fund-supported programs.

Disaggregated military spending data are only requested when these are needed to assess the impact of military spending on macroeconomic aggregates. For example, it might be necessary to have information on the wage component of military spending if a large increase in wages for military personnel is envisaged. In cases where disaggregated information is not necessary, staff seek information that permits the reporting of an economic and functional classification of fiscal expenditures.

Fund staff also monitor trends in world-wide military spending as found in various data sources. The results from such analyses have been widely disseminated.

Transparency of fiscal accounts is addressed in the context of the Fund's reports on the Observance of Standards and Codes (fiscal ROSCs). Under the ROSCs, which are a voluntary exercise for members, the transparency of fiscal operations is assessed relative to best practice. As of January 2004, 63 fiscal ROSCS have been completed, of which 58 are available on the Fund's external website (www.imf.org). To help prepare for fiscal ROSCs, countries are asked to provide answers to a questionnaire on fiscal transparency. As part of these questions, countries are asked whether military expenditure is reported in the budget and whether annual accounts are sufficiently comprehensive and detailed. In addition, the questionnaire asks whether the findings of the national audit body are available to the public, including audits of military spending.

der conflict. The latest proposal for World Bank (IBRD)/IMF collaboration on public expenditure issues reflects the expansion of activities of the World Bank and the IMF in public expenditure work and the continuous strengthening of World Bank/IMF co-operation. ${ }^{14}$

The establishment of the Public Expenditure and Financial Accountability (PEFA) partnership in 2001 provides the basis for broader collaboration on public expenditure issues with the Bank and the Fund. ${ }^{15}$ The PEFA program supports integrated and harmonized approaches to assessment and reform of public expenditure, procurement and financial management systems. While still in its early stages, consultations among PEFA members have served to expand support for the new framework by incorporating the perspectives of bilateral development partners and the EC. The potential for incorporating the management of defence expenditure under this multi-agency initiative could be explored.

14 Bank/Fund Collaboration on Public Expenditure Issues, prepared by the IMF's Fiscal Affairs Department and the World Bank's Poverty Reduction and Economic Management Network, in collaboration with other departments of the IMF and the World Bank, Approved by Teresa Ter-Minassian and Gobind Nankani, February 14, 2003.

15 The PEFA program is a partnership of the World Bank, European Commission, the Fund, UK Department for International Development, Swiss State Secretariat for Economic Affairs, French Ministry of Foreign Affairs, Norwegian Ministry of Foreign Affairs, and Strategic Partnership with Africa. The PEFA program is managed by a Steering Committee consisting of headquarters representatives of the member agencies.

\section{Proposal for Follow-on Action: Applying PEM to the Defence Sector}

As a group, workshop participants bring to the table a broad range of experience necessary to assist partner countries to improve the quality of public expenditure management in the defence sector. An appropriate result would be to agree on follow-on action that helps to establish a standing partnership of bilateral and multilateral actors willing to support partner countries in this field.

Obviously, most bilateral donors and multilateral agencies have not been very active in supporting financial management in the defence sector. Therefore, it seems useful to deepen the exchange on practical experiences gathered so far, to strengthen capacity building at the side of donors and development agencies and to embark on joint activities that help to establish co-operation mechanisms.

Box 5

\section{Capacities of Selected Utstein Members}

Within the Utstein group, the capacity to support public expenditure work in the defence sector is mixed. The United Kingdom clearly has the greatest capacity in terms of both public expenditure expertise and experience in promoting defence reform in developing and transition countries. DFID frequently works closely with the Bank on assessments of public expenditure systems in partner countries, and supports PRSP development. Through the Defence Advisory Team (DAT), it has provided support for defence reform efforts in some 18 countries, including several defence review processes that could lay the basis for subsequent defence budgeting work. Both the DAT and the UK Ministry of Defence have the capacity to provide technical assistance to countries seeking to improve their defence budgeting capabilities. Through the Global Facilitation Network, the UK is supporting civil society networks in developing countries aimed at improving knowledge of security-related issues.

Other Utstein partners, like Germany, are in the process of enhancing their capacities in this regard. The German Agency for Technical Co-operation (GTZ) is implementing a security-sector reform program with the aim of providing advisory services on different intervention levels (political/legal, institutional/ technical and societal). As well there is a program on »Public Finance and Administrative Reform «, which aims at providing expertise in budgetary processes and procedures to MOF (Ministries of Finance), state audit institutions and budget departments of sector ministries; in this regard, activities with regards to military budgets are on the agenda as well. Additionally, KfW development bank could join other donor activities on PER in those countries where development assistance is involved in co-financing PRSC (Poverty Reduction Support Credit) or MDBS (Multi-Donor Budget Support). Moreover, other German development agencies and the Political Foundations are willing to contribute to strengthening civil-military dialogue and capacity building of security bodies as well as legislative or oversight bodies.

The Netherlands is also developing its capacity to undertake work in this area. It has developed an assessment framework »Enhancing Democratic Governance of the Security Sector « that includes the quality of financial management in the security sector as one entry point. This assessment framework is expected to be piloted jointly with other bilateral donors during 2004 . The Public Finance Management (PFM) Support Unit within the Ministry of Foreign Affairs consists of a team of (senior) PFM staff and a secretariat. The PFM Support Programme aims at enhancing capacity with respect to PFM and the budget process within both the Ministry and Netherlands Embassies in countries where the Netherlands has a structural bilateral development relationship. These bilateral development relationships are based upon a sectoral approach and include budgetary support and assistance in sector-wide reforms. The Netherlands has created a new financing facility, called the »Stability Fund «, in order to support and improve the effectiveness of a more integrated approach to peace, security and development. The Fund will draw on ODA as well as non-ODA sources, and could be used to finance PEM activities as part of SSR. 